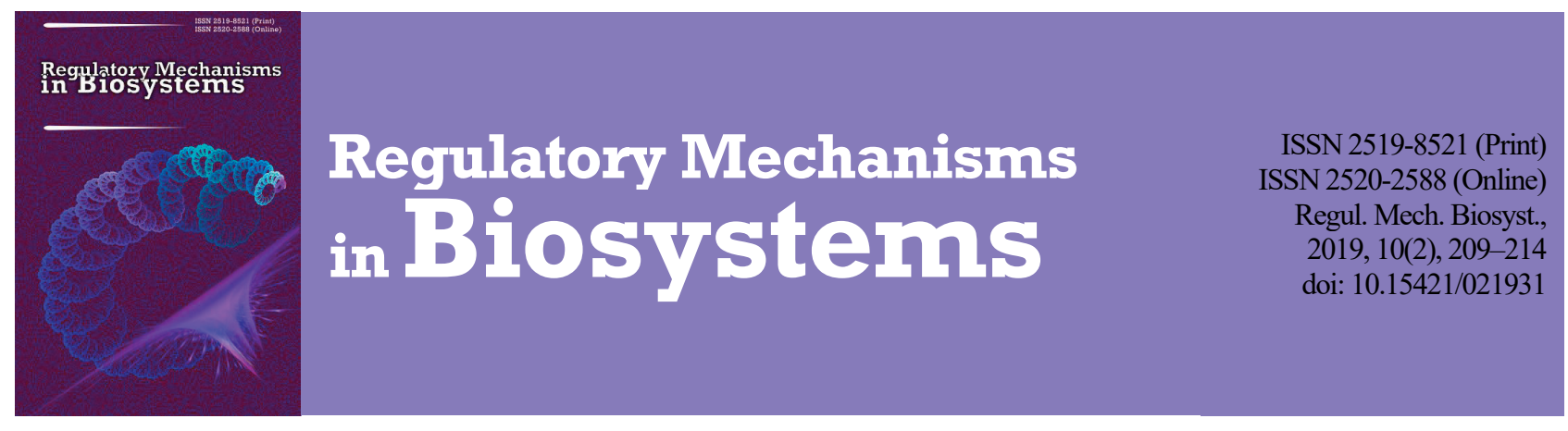

\title{
Influence of chromium citrate on oxidative stress in the tissues of muscle and kidney of rats with experimentally induced diabetes
}

\author{
O. O. Sushko, R. J. Iskra, L. I. Ponkalo
}

Institute of Animal Biology NAAS, Lviv, Ukraine

Article info

Received 05.04.2019 Received in revised form 12.05.2019 Accepted 13.05.2019

Institute of Animal Biology NAAS,

V. Stus st., 38,

Lviv, Ukraine, 79034

Tel.: + 38-098-410-80-39.

E-mail:

sushko.ola@gmail.com

\begin{abstract}
Sushko, O. O., Iskra, R. J., \& Ponkalo, L. I. (2019). Influence of chromium citrate on oxidative stress in the tissues of muscle and kidney of rats with experimentaly induced diabetes. Regulatory Mechanisms in Biosystems, 10(2), 209-214. doi:10.15421/0219231
\end{abstract}

\begin{abstract}
Chromium is one of the important trace elements that is essential for carbohydrate, protein and lipid metabolism. Chromium improves glucose metabolism and reduces insulin resistance due to increased insulin sensitivity. Therefore, it is important to consider the use of chromium citrate as a nutritional supplement with potential hypoglycemic and hypolipidemic effects. In this research work, we investigated the activity of the antioxidant system and the level of lipid hydroperoxides in the tissues of skeletal muscles and kidneys of experimental diabetic rats and for rats which received in their daily diet chromium citrate in the amounts $0.1 \mathrm{and} 0.2 \mu \mathrm{g} / \mathrm{mL}$ of water. We induced the experimental model of diabetes by intraperitoneal injection of alloxan in the amount $150 \mathrm{mg} / \mathrm{kg}$ of body weight of the animals. We monitored glucose levels by measuring daily glucose levels with a portable glucose meter. For research, we selected animals with a glucose level $>11.1 \mathrm{mmol} / \mathrm{L}$. We monitored the body weight of rats. On the 40th day of the study, we withdrew the animals from the experiment by decapitation. We selected the tissue for research, namely skeletal muscles and kidneys. In samples of the tissue homogenates, we measured the activity of antioxidant enzymes and the content of lipid peroxide oxidation products. As a result of our research, we found that the products of lipid peroxide oxidation and glutathione peroxidase activity increased in skeletal muscle of animals with diabetes mellitus. The activity of glutathione reductase, catalase, superoxide dismutase, and the content of reduced glutathione decreased at the same time. In the kidneys of diabetic rats, the activity of glutathione peroxidase, glutathione reductase, catalase and content of lipid hydroperoxides increased but the activity of superoxide dismutase and the content of reduced glutathione decreased. The addition of chromium citrate to the diet of animals in amounts 0.1 and $0.2 \mu \mathrm{g} / \mathrm{mL}$ led to the suppression of oxidative stress. The activity of catalase, glutathione peroxidase and the content of lipid hydroperoxides, TBA-positive substances decreased. Also, the activity of superoxide dismutase increased with the addition of chromium citrate. These results indicate normalization of antioxidant defense in the skeletal muscle and kidneys of experimental rats with experimental diabetes given chromium citrate in the amount $0.1 \mathrm{mg} / \mathrm{mL}$ of water
\end{abstract}

Keywords: antioxidant defense; lipid peroxidation; alloxan; hyperglycemia.

\section{Introduction}

Deficiency and accumulation of mineral elements in the human body are often due to environmental pollution, malnutrition and metabolic disorders. The optimal amount of macro- and trace elements in the body is a prerequisite for the preservation and strengthening of human health. They participate in various physiological functions of the body, which include immune regulation with the help of humoral and cellular mechanisms, neuronal conduction, muscle contraction, membrane potential regulation, mitochondrial activity and enzyme response (Siddiqui et al., 2014; Devi et al., 2016). Some trace elements can also be involved in the pathogenesis of diet-dependent diseases such as diabetes (Stanieka \& Wójciak, 2018).

Diabetes mellitus (DM) is a chronic metabolic disorder that occurs due to absolute or relative insulin deficiency. Disorder of the secretion of this hormone affects glucose metabolism, which leads to hyperglycemia (Praveena et al., 2013; Asmat et al., 2016). What is important is that diabetes disrupts most metabolic processes and increases the risk of damage to the tissues of the body, which ultimately leads to serious complications. Yet, it is known that a diabetic condition is often accompanied by an inability to maintain a functional state of muscle tissue. There is a disorder of the sensitivity of cells of this tissue to insulin, a decrease in glucose and its intracellular metabolism in skeletal muscles in the central nervous system (Coleman et al., 2015). This leads to a decrease in the size of the muscle mass, poor metabolic control and the transition to the glycolytic pathway of glucose oxidation (Krause et al.,
2013). Blood vessels of the kidneys are damaged in patients with diabetes mellitus. The first sign of kidney damage is the appearance of albumin in the urine. Kidneys affected by the disease do not sufficiently clean blood, so they collect waste. Diabetic nephropathy is one of the most common and serious complications of diabetes characterized by albuminuria, high blood pressure, gradual renal dysfunction, and ultimately leads to a terminal stage of renal failure. Renal gluconeogenesis significantly promotes glucose homeostasis (Pecoits-Filho et al., 2016).

Oxidative stress is considered as an integral part of the pathogenesis of diabetes mellitus and its complications. Today, the available medication for DM mimicking the effects of insulin has side effects and this is why there is a growing need for new pharmacological agents that can improve insulin sensitivity and have antioxidant properties (Lipko \& Debski, 2018). The trace element of chromium (Cr, III) is a part of the oligopeptide of chromodulin, which activates the action of insulin by promoting hormone binding with receptors on the cell surface (Vincent, 2015; Nagarjun et al., 2017). Biological efficiency of many organic compounds of chromium, including chromium picolinate, chromium nicotinate, chromium histidinate, chromium d-phenylalanine, chromium propionate and chromium glycinate has been demonstrated. Organic chromium compounds are used in pharmacy as antidiabetic supplements (Dhama et al., 2017).

There are a number of studies that have shown that chromium is important for the exchange of glucose and lipids in the body (Yin \& Phung, 2015; Yang et al., 2016; Wang, et al., 2016; Zhang et al., 2017). In skeletal muscle cells of rats, chromium increases the level of insulin 
and significantly increases the level of insulin mRNA receptor, glycogen synthase and glucose transport 4 (Qiao et al., 2009).

There is the evidence of toxicity of some chromium compounds. For example, chromium pycolinate is most often used as a dietary supplement for regulating intracellular glucose metabolism associated with insulin resistance. However, it has been shown that this compound with chromium can generate hydroxyl radicals and carry out oxidative damage to DNA (Stallings et al., 2006). In order to reduce the toxicity and improve the absorption of chromium tissue, organic ligands with less toxicity are used and such compounds are of great interest to researchers (Król \& Krejpcio, 2010). Citric acid is a natural organic acid that is not toxic to humans and the environment and is widely used in the food, pharmaceutical and cosmetic industries. Therefore, we chose chromium citrate for research.

The objective of the research was determining the effect of chromium citrate on the state of the antioxidant system in the tissues of skeletal muscles and kidneys of rats with experimental diabetes.

\section{Materials and methods}

Chemical/drug used. The solution of chromium citrate was obtainned by the method of erosion-explosive nanotechnology (Patent 23550). This method is used to obtain an aqueous colloidal solution of nanoparticles of chromium using electropulse aqua technology, which, after direct interaction with citric acid, forms chromic citrate - a product of high chemical purity $(99.9 \%)$. When there is a sufficient amount of citric acid, chromium citrate does not contain nanoparticles, whose biological effects are hard to predict. The excess of citric acid increases the complexity of the composition of nanoparticles and, consequently, their bioavailability. Alloxan monohydrate produced by Synbias (Ukraine) molecular weight 160.10 .

Animals and diets. The research was conducted on 32 white laboratory rats (male) kept in the vivarium of the Institute of Animal Biology of the NAAS (12-h cycle of light/darkness). All animals were kept at temperature $\left(24 \pm 1{ }^{\circ} \mathrm{C}\right)$ and humidity $(45 \pm 5 \%)$. All animals were clinically healthy, received standard granular feed for laboratory rats. Rats weighing 100-120 g were divided into 4 groups: I and II groups control groups. The rats from these groups were given pure water without any supplements. III and IV - experimental groups, animals were given water with the solution of chromium citrate in the amounts of 0.1 and $0.2 \mu \mathrm{g} / \mathrm{mL}$ of water. On the 31 st day of the study, the diabetes mellitus was induced in animals from the II, III and IV groups.

On the 40th day of the study, the animals were withdrawn from the experiment and were decapitated under light ether anesthesis. The experiment was conducted according to the provisions of the "European Convention for the Protection of Vertebrate Animals used for Experiments and Other Scientific Purposes" (Strasbourg, 1985) and "General Ethical Principles of Animal Experiments" adopted by the First National Congress on Bioethics (Kyiv, 2001).

Induction of diabetes mellitus. Diabetes mellitus was induced by intraperitoneal administration of $5 \%$ solution of alloxan monohydrate in the amount of $150 \mathrm{mg} / \mathrm{kg}$ of body weight after a 24-h fasting period (Katsumata et al., 1999). In order to detect hyperglycemia, we collected blood from the tail vein and measured glucose level in the collected blood using a portable glucose meter (Gamma-M, UK). Dynamics of changes in glucose level were taken immediately before the start of the experiment, on the 1st, 15th and 30th days of the experiment, and continued after the injection of alloxan on the 32nd, 36th and 40th days of studies. Glucose level in the blood $>11.1 \mathrm{mmol} / \mathrm{L}$ in rats was accepted as a successful induction of diabetes mellitus (Xie et al., 2010). The normal healthy rats were injected $0.9 \%$ of physiological saline.

Analytical methods. We used homogenates of skeletal muscles and kidney tissue as the material for the study. The homogenate was prepared using $0.05 \mathrm{M}$ Tris- $\mathrm{HCl}$ buffer, $\mathrm{pH}$ of $7.8(1 \mathrm{~g}$ of tissue and $10 \mathrm{~mL}$ of buffer). The concentration of protein in the homogenates of the tissue was determined by Lowry's method (Lowry et al., 1951). The content of lipid hydroperoxides (LPO) in the homogenates was determined by the method the principle of which is based on the precipitation of protein with a solution of trichloroacetic acid, followed by the introduction of ammonium thiocyanate (Myronchik, 1998). The concentration of TBA-positive substance was measured using the colour reaction of malonic dialdehyde with thiobarbituric acid (Korobeynikova, 1989). Superoxide dismutase (SOD, EC 1.1.15.1) activity was determined by the method the principle of which lies in the restoration of nitrotetrazolium by superoxide radicals (Dubinina et al., 1988). Glutathione peroxidase activity (GPx, EC 1.11.1.9) was determined using the rate of oxidation of reduced glutathione (Moin, 1996). Catalase activity (CAT, EC 1.11.1.6) was determined by the ability of hydrogen peroxide to produce a stable stained complex with molybdenum salts (Korolyuk et al., 1988). Glutathione reductase activity (GR, EC 1.6.4.2) was determined by the rate of glutathione recovery in the presence of NADPH (Bergmeyer, 1974). The content of reduced glutathione (GSH) was determined by the level of formation of thionitrophenyl anion as a result of the interaction of the SH group of glutathione with 5.5dithiobium, 2-nitrobenzoic acid (Vlizlo et al., 2012).

Statistical analysis. Digital material that was obtained during the research was processed with the method of variational statistics using ANOVA. Average arithmetic values $(\mathrm{x})$ and standard error $( \pm \mathrm{SE})$ were calculated. Changes were considered significant at $\mathrm{P}<0.05$.

\section{Results}

Effect on blood glucose levels. Alloxan is used to induce experimental diabetes as a result of selective damage to the ultrasound of the $\beta$-cells of the Langerhans of the pancreas producing insulin. Changes in the concentration of insulin in blood plasma lead to changes in blood glucose levels. In animals from the control groups, glucose level fluctuated during the experiment in the range of $5.69-6.94 \mathrm{mmol} / \mathrm{L}$. For the rats from the II group with diabetes, the rate varied from $5.88 \mathrm{mmol} / \mathrm{L}$ - at the beginning of the trial to $16.25 \mathrm{mmol} / \mathrm{L}$ - for the first day and $22.93 \mathrm{mmol} / \mathrm{L}$ - on the 10th day after the injection of alloxan, which confirms the emergence of significant hyperglycemia. In the experimental groups, drinking of a solution of chromium citrate reduced the indices of glucose level in the blood of animals with DM. In the III group, the glucose level at the beginning of the trial was $6.05 \mathrm{mmol} / \mathrm{L}$, the first day after the injection of alloxan $15.73 \mathrm{mmol} / \mathrm{L}$ and on the 10th day after the administration of the drug $16.91 \mathrm{mmol} / \mathrm{L}$. In the IV group, this index varied from $6.61 \mathrm{mmol} / \mathrm{L}$ - at the beginning of the trial, to $15.83 \mathrm{mmol} / \mathrm{L}$ - on the first day after administration of alloxan and $18.64 \mathrm{mmol} / \mathrm{L}$ - on the 10th day after the administration of the drug. The results obtained indicate that citrate may alter blood glucose level in animals with diabetes mellitus.

\section{Table 1}

Blood glucose dynamics of rats in control (I) group, in group with experimental diabetes (II) and groups exposed to the effects of chromium citrate in the amounts of 0.1 (III) and $0.2 \mu \mathrm{g} / \mathrm{mL}$ (IV) $(\mathrm{x} \pm \mathrm{SE}, \mathrm{n}=8)$

\begin{tabular}{|c|c|c|c|c|c|c|c|}
\hline \multirow{3}{*}{$\begin{array}{l}\text { Animal } \\
\text { groups }\end{array}$} & \multicolumn{7}{|c|}{ Time periods of the experiment } \\
\hline & \multirow{2}{*}{0 day } & \multirow{2}{*}{1 day } & \multirow[t]{2}{*}{15 day } & \multirow[t]{2}{*}{30 day } & \multicolumn{3}{|c|}{$\begin{array}{l}\text { after the one injection of } 0.9 \% \text { of physiological saline (I group) and of } 5 \% \text { solution of } \\
\text { alloxan monohydrate ( } 150 \mathrm{mg} / \mathrm{kg} \text { of body weight) (II, III, IV groups) on } 31 \text { Day }\end{array}$} \\
\hline & & & & & 32 Day & 36 Day & 40 Day \\
\hline I & $6.94 \pm 0.17$ & $5.76 \pm 0.15$ & $5.88 \pm 0.27$ & $5.69 \pm 0.38$ & $6.26 \pm 0.44$ & $6.16 \pm 0.44$ & $5.90 \pm 0.46$ \\
\hline II & $5.88 \pm 0.26^{* *}$ & $6.49 \pm 0.31$ & $6.35 \pm 0.19$ & $5.46 \pm 0.20$ & $16.25 \pm 1.29^{* * *}$ & $17.24 \pm 1.09^{* * *}$ & $22.93 \pm 1.57^{* * *}$ \\
\hline III & $6.05 \pm 0.45$ & $5.91 \pm 0.24^{\#}$ & $5.71 \pm 0.13^{\#}$ & $4.64 \pm 0.32$ & $15.73 \pm 1.37^{* * *}$ & $16.25 \pm 1.39^{* * *}$ & $16.91 \pm 1.46^{* * * \#}$ \\
\hline IV & $6.61 \pm 0.22$ & $6.05 \pm 0.10^{\#}$ & $5.86 \pm 0.09^{\#}$ & $6.26 \pm 0.30$ & $15.83 \pm 1.11^{* * *}$ & $17.10 \pm 1.21^{* * *}$ & $18.64 \pm 1.53^{* * *}$ \\
\hline
\end{tabular}

Notes: probability of indices of II, III and IV groups relative to I group * $-\mathrm{P}<0.05, * *-\mathrm{P}<0.01, * * *-\mathrm{P}<0.001$; probability of indices of III and IV groups relative to II group ${ }^{\#}-\mathrm{P}<0.05,{ }^{\#}-\mathrm{P}<0.01,{ }^{\ldots}-\mathrm{P}<0.001$. 
Measurements of body weight. Body mass was measured at baseline and throughout the study. At the beginning of the experiment, all animals from the research groups showed a slight difference in their body weight. On the 40th day the body weight of the experimental animals showed a decrease by $26.6 \%(\mathrm{P}<0.001)$ in the II diabetic group compared with the control group I. The body weight of animals significantly decreased in the experimental groups III and IV by $17.3 \%$ and $19.8 \%(\mathrm{P}<0.001)$ compared with the control group I. The body mass index significantly increased with the effects of chromium citrate by $12.7 \%(\mathrm{P}<0.001)$ and $9.6 \%(\mathrm{P}<0.01)$ in the experimental groups III and IV compared with the II diabetic group.

Effect on lipid peroxidation and oxidative stress biomarkers. In the muscles of rats from the II group with diabetes the content of LPO increased by $141.8 \%(\mathrm{P}<0.001)$ and TBA-positive substances by $33.6 \%$ $(\mathrm{P}<0.01)$ as compared to the control group I. This indicates the activation of lipid peroxidation processes in the modeling of diabetes and the enhancement of oxidative stress in rats (Table 2).

\section{Table 2}

The content of lipid peroxidation products and the activity of antioxidant enzymes in skeletal muscles in rats with experimental diabetes (II) and exposed to the action of chromium citrate in amounts of 0.1 (III) and $0.2 \mu \mathrm{g} / \mathrm{mL}$ (IV) $(\mathrm{x} \pm \mathrm{SE}, \mathrm{n}=8)$

\begin{tabular}{lcccc}
\hline \multicolumn{1}{c}{ Indicators } & \multicolumn{4}{c}{ Animal groups } \\
\cline { 2 - 5 } in skeletal muscles & $\mathrm{I}$ & $\mathrm{II}$ & $\mathrm{III}$ & $\mathrm{IV}$ \\
\hline Lipid hydroperoxide, & 0.28 & 0.68 & 0.47 & 0.52 \\
OE/mL & \pm 0.03 & $\pm 0.10^{* * *}$ & $\pm 0.04^{* * *}$ & $\pm 0.04^{* * *}$ \\
TBA-positive substances, & 2.82 & 3.77 & 3.45 & 3.93 \\
$\mathrm{nmol} / \mathrm{mL}$ & \pm 0.22 & $\pm 0.2^{* *}$ & \pm 0.22 & $\pm 0.22^{* *}$ \\
Catalase, & 7.91 & 6.77 & 7.09 & 6.56 \\
$\mu \mathrm{mol} / \mathrm{min} \times$ mg of protein & \pm 0.21 & \pm 0.64 & \pm 0.36 & $\pm 0.36^{* *}$ \\
Superoxide dismutase, & 15.40 & 12.19 & 14.31 & 11.01 \\
U/mg of protein & \pm 0.74 & $\pm 0.96^{*}$ & $\pm 0.16^{\#}$ & $\pm 0.35^{* * *}$ \\
Glutathione peroxidase, & 37.72 & 47.67 & 39.32 & 42.70 \\
$\mu \mathrm{mol} / \mathrm{min} \times$ mg of protein & \pm 2.03 & $\pm 2.62^{* *}$ & $\pm 1.40^{\#}$ & \pm 2.70 \\
Glutathione reductase, & 2.31 & 1.88 & 2.05 & 1.98 \\
$\mu \mathrm{mol} /$ min $\times$ mg of protein & \pm 0.10 & \pm 0.24 & \pm 0.12 & \pm 0.16 \\
Reduced glutathione, & 0.04 & 0.03 & 0.04 & 0.03 \\
mmol/L & \pm 0.01 & $\pm 0.00^{*}$ & $\pm 0.00^{\# *}$ & \pm 0.00 \\
\hline
\end{tabular}

Notes: probability of indices of II, II and IV groups relative to 1 group * $\mathrm{P}<0.05, * *-\mathrm{P}<0.01, * * *-\mathrm{P}<0.001$; probability of indices of III and IV groups relative to II group ${ }^{\#}-\mathrm{P}<0.05,{ }^{\#}-\mathrm{P}<0.01$, $-\mathrm{P}<0.001$.

With the addition of chromium citrate to the diet of rats, the content of lipid peroxidation products somewhat decreased. In particular, in the III group, we observed an increase in the content of LPO by $66.7 \%(\mathrm{P}<$ 0.01 ) as compared to the I group and a decrease in its content by $31.1 \%$ $(\mathrm{P}<0.05)$ as compared to the II group. In the IV group, this indicator increased by $85.3 \%(\mathrm{P}<0.001)$ compared with the control I group, and slightly decreased with respect to the II group.

The content of TBA-positive substances in skeletal muscle of animals from the groups III and IV was not significantly different as compared to group II, but in group IV it increased by $39.5 \%(\mathrm{P}<0.01)$ compared with the control group I. Consequently, the content of TBApositive substances is a good indicator for assessing oxidative stress in degenerative diseases such as diabetes mellitus.

The superoxide anion belongs to the active forms of oxygen and is considered to be one of the initiators of free radical reactions. The activity of SOD decreased by $20.9 \%(\mathrm{P}<0.05)$ in the tissues of skeletal muscles in the II group compared to the control group I. The catalase catalytically converts $\mathrm{H}_{2} \mathrm{O}_{2}$ into water and oxygen, and thus neutralizes it. We observed a decrease in the activity of this enzyme by $14.4 \%$ in tissues of skeletal muscles of animals from the II group with diabetes.

The activity of the CAT decreased by $17.1 \%(\mathrm{P}<0.01)$ and the activity of SOD decreased by $28.5 \%(\mathrm{P}<0.001)$ in the skeletal muscles of animals from group IV compared with control I group. For the introduction of chromium citrate in the amount of $0.1 \mu \mathrm{g} / \mathrm{mL}$ of water, the activity of SOD increased by $14.4 \%(\mathrm{P}<0.05)$ in the skeletal muscles of animals of the III group, while the catalase only increased by $4.7 \%$ compared to animals of the diabetic II group. In the animals from the II group under conditions of diabetes, GPx-activity increased by $26.4 \%$
$(\mathrm{P}<0.01)$ in the tissues of skeletal muscles. At the same time, GRactivity was directed towards decrease in the muscles of animals of the II group. The content of reduced glutathione also decreased by $34.8 \%$ $(\mathrm{P}<0.05)$ during diabetes in muscle of animals in II group $(\mathrm{P}<0.05)$ comperd with the control, which is apparently due to glutathione reductase dysfunction.

In the animals which were given chromium citrate in an amount of $0.1 \mu \mathrm{g} / \mathrm{mL}$ of water, the activity of the GPx decreased in skeletal muscles of animals of the III group by $17.5 \%(\mathrm{P}<0.05)$ compared with the II diabetic group. Activity of GR increased slightly in the III and IV groups, but these changes were not significant. The content of GSH increased by $40 \%(\mathrm{P}<0.01)$ in the muscles of animals of the III group in relation to the diabetic II group. Lower concentrations of chromium citrate showed greater efficacy in normalizing the antioxidant defense system in skeletal muscle of rats.

The content of LPO increased by $157.1 \%(\mathrm{P}<0.001)$ in the kidneys of animals in group II with diabetes compared with the I control group (Table 3 ). The content of LPO significantly increased by $121.3 \%$ $(\mathrm{P}<0.001)$ and $158.3 \%(\mathrm{P}<0.01)$ in the kidneys of animals from groups III and IV, respectively, compared with the group I. The content of TBK-positive substances increased significantly by $25.7 \%(\mathrm{P}<0.05)$ in the kidneys of animals of the II group. The content of LPO decreased by $13.9 \%(\mathrm{P}<0.05)$ and TBK-positive substances decreased by $22.8 \%$ $(\mathrm{P}<0.01)$ in the kidneys of animals from the group III under the action of chromium citrate in the amount of $0.1 \mu \mathrm{g} / \mathrm{mL}$ as compared to the II group.

\section{Table 3}

The content of lipid peroxidation products and the activity of antioxidant enzymes in kidneys of rats with experimental diabetes (II) and subject to the action of chromium citrate in amounts of 0.1 (III) and $0.2 \mu \mathrm{g} / \mathrm{mL}$ (IV) $(\mathrm{x} \pm \mathrm{SE}, \mathrm{n}=8)$

\begin{tabular}{lcccc}
\hline \multirow{2}{*}{ Indicators in kidneys } & \multicolumn{4}{c}{ Animal groups } \\
\cline { 2 - 5 } & $\mathrm{I}$ & $\mathrm{II}$ & $\mathrm{III}$ & $\mathrm{IV}$ \\
\hline Lipid hydroperoxide, & 0.13 & 0.34 & 0.29 & 0.34 \\
OE/mL & \pm 0.03 & $\pm 0.20^{* * *}$ & $\pm 0.01^{* * * *}$ & $\pm 0.05^{* *}$ \\
TBA-positive substances, & 3.25 & 4.09 & 3.15 & 3.66 \\
$\mathrm{nmol} / \mathrm{mL}$ & \pm 0.21 & $\pm 0.28^{*}$ & $\pm 0.11^{\text {\#\# }}$ & \pm 0.37 \\
Catalase, & 13.23 & 16.54 & 15.47 & 11.84 \\
$\mu$ mol/min $\times$ mg of protein & \pm 0.85 & \pm 1.37 & \pm 1.17 & $\pm 0.74^{\text {\#\# }}$ \\
Superoxide dismutase, & 15.80 & 11.37 & 13.84 & 11.41 \\
U/mg of protein & \pm 0.60 & $\pm 0.39^{* * *}$ & $\pm 0.43^{* \ldots \#}$ & $\pm 0.75^{* * *}$ \\
Glutathione peroxidase, & 65.96 & 78.22 & 75.85 & 60.29 \\
$\mu$ mol/min $\times$ mg of protein & \pm 2.69 & $\pm 3.43^{*}$ & \pm 3.83 & $\pm 3.66^{\# \#}$ \\
Glutathione reductase, & 3.37 & 5.98 & 4.84 & 5.78 \\
$\mu$ mol/min $\times$ mg of protein & \pm 0.43 & $\pm 0.34^{* * *}$ & $\pm 0.46^{*}$ & $\pm 0.43^{* *}$ \\
Reduced glutathione, & 0.68 & 0.60 & 0.61 & 0.60 \\
mmol/L & \pm 0.02 & $\pm 0.01^{* *}$ & $\pm 0.01^{* *}$ & $\pm 0.03^{*}$ \\
\hline
\end{tabular}

Notes: probability of indices of II, III and IV groups relative to I group * $\mathrm{P}<0.05, * *-\mathrm{P}<0.01, * * *-\mathrm{P}<0.001$; probability of indices of III and IV groups relative to II group ${ }^{\#}-\mathrm{P}<0.05,{ }^{\prime}-\mathrm{P}<0.01,{ }^{\prime \prime}-\mathrm{P}<0.001$.

The activity of CAT increased in the kidneys of animals from the II group with diabetes, but it was not significant. This activity decreased by $28.5 \%(\mathrm{P}<0.01)$ in the animals which received chromium citrate in amounts of $0.2 \mu \mathrm{g} / \mathrm{mL}$ of water as compared to the II diabetic group, which emphasizes the positive dynamics of normalization of catalase activity due to the action of this compound.

In the kidneys of animals of the II, III and the IV groups, the activity of SOD decreased by $28.0 \%(\mathrm{P}<0.001), 12.4 \%(\mathrm{P}<0.05)$ and $27.8 \%(\mathrm{P}<0.001)$ compared with the I control group. Chromium citrate in amounts of $0.1 \mu \mathrm{g} / \mathrm{mL}$ of water resulted in an increase by $21.7 \%(\mathrm{P}<$ 0.001 ) in the enzymatic activity in the tissue of animals of the III group as compared to the II diabetic group.

The GPx activity in the kidneys of animals from the II diabetic group increased by $18.6 \%(\mathrm{P}<0.05)$ compared with the control group I. In the kidneys of rats of the IV group given chromium citrate in amounts of $0.2 \mu \mathrm{g} / \mathrm{mL}$ of water, the activity of GPx decreased by $22.9 \%$ (P $<0.01)$ compared with the II group.

The activity of GR in the kidneys of rats from II, III and the IV groups increased by $77.3 \%(\mathrm{P}<0.001), 47.4 \%(\mathrm{P}<0.05)$ and $71.3 \%$ $(\mathrm{P}<0.01)$, respectively, compared with the control group I. The content 
of reduced glutathione significantly decreased in the tissues of animals from groups II, III and IV, respectively, by $12.0 \%(\mathrm{P}<0.01), 10.5 \%$ $(\mathrm{P}<0.01)$ and $12.5 \%(\mathrm{P}<0.05)$ compared with the control group I.

\section{Discussion}

The relationship between diabetes mellitus and trace elements is described in many scientific works. Micronutrients in the natural environment may be responsible for genetic and epigenetic changes in the body that lead to the development of type 1 diabetes (Valera et al., 2014).

It is known that trace elements, especially chromium $(\mathrm{Cr})$, play a significant role in the metabolism of lipids and carbohydrates (Feng et al., 2015). Chromium as a cofactor of chromodulin, a low molecular weight oligopeptide, by attaching to the $\beta$-subunit of the insulin receptor and activating tyrosine kinase, increases the effect of insulin. This leads to the activation of GLUT4, which carries glucose transport through the cell membrane. Such chromium-activated glycolytic pathways allow muscle and fat cells to absorb and convert glucose into triacylglycerol (Lewicki et al., 2014).

Chromium, as a factor of glucose tolerance, plays an important part in the metabolism of this carbohydrate. In some research studies on laboratory animals and humans, chromium was found to have a positive effect on the exchange of glucose and insulin (Martin et al., 2006).

Diabetes is a disease that is believed to be associated with elevated oxidative stress, because it is associated with increased concentrations of lipid peroxidation. AFO modifies lipids, carbohydrates, proteins and nucleic acids, which leads to cytotoxicity and cell dysfunction. It is believed that hyperglycemia generates abnormally high levels of AFO, which leads to oxidative degeneration and glycation of proteins (Evans et al., 2002). Oxidation stress worsens myogenesis. Aragno et al. (2004) found that the expression of critical myogenic factors was reduced in diabetic rats compared to healthy ones, which caused muscle damage.

Alloxan is a $\beta$-cytotoxin which induces chemical diabetes, thereby damaging the cells of the pancreas. This experimental diabetes mellitus model corresponds to type I diabetes, where insulin secretion is impaired. Literary sources indicate that alloxan diabetic rats are hyperglycemic (Ozaki et al., 2018). Glycemic measurements confirmed that rats with alloxan-induced diabetes had an elevated glucose level compared with control animals. In experimental groups, when giving animals a solution of chromium citrate, there is a tendency towards decrease in this indicator. Chromium compounds lower glycosylated hemoglobin and glucose levels in patients with type 2 diabetes (Martin et al., 2006). That is, chromium exhibits antidiabetic effect and, in our opinion, this antihyperglycemic effect of chromium may be associated with an increase in glucose uptake by increasing the number or enhancement of translocation of glucose transporters.

Data obtained in this study showed that alloxan significantly decreased the body weight of animals with DM compared to the control group. The same result is also confirmed by the studies by other authors (Fu et al., 2007). The mass increased in comparison with the II diabetic group when the chromium compounds were introduced into the diet of experimental rats, although there was no probable change in body mass. In studies by some authors (Yang et al., 2005), there was no relationship between body weight of rats and the effect of chromium compounds, these rats receiving chromium picolinate in their ration. However, in other studies chromium pycolinate was found to significantly affect the final weight of the body, body weight gain, growth rate, nutritional efficiency in the body of fish (Li et al., 2018).

Oxidative stress is accelerated in the body of living creatures with diabetes. The first line of protection against free radicals combines the following enzymes: SOD, CAT, GPx.

SOD provides first-line protection by catalyzing a portion of superoxide, primary AFO in the process of oxygen exchange to molecular oxygen and hydrogen peroxide. We have determined a decrease in the activity of this enzyme, which is an indicator of depletion of protective properties of the enzyme. In the skeletal muscle of diabetic rats, this decline is due to an increase in the production of free radicals and AFOs (Guan et al., 2016). CAT catalyzes the conversion of hydrogen peroxide and protects tissues from reactive hydroxyl radicals (Chandirasegaran et al., 2018). The activity of CAT decreased in skeletal muscle of diabetic rats compared to control animals. Hyperglycemia is the main cause of elevated levels of free radicals, after which an AFO occurs, which may lead to an increase of lipid perioxidation and changes in the antioxidant defense of the body. Kidneys are highly susceptible to oxidative stress, most likely due to the high content of polyunsaturated fatty acids in the kidney lipids. CAT increased its activity somewhat in the tissues of the kidneys.

The level of reduced glutathione decreased during diabetes. GPx catalyzes the decrease of lipid peroxidation levels due to this enzyme. $\mathrm{H}_{2} \mathrm{O}_{2}$ also inactivates the GPx, which increases the consumption of GSH (Kumawat et al., 2013).

TBA-positive substances significantly increased in patients with I type DM in research studies by Neve et al. (1995). A number of scientists have found that levels of TBA-positive substances and hydrogen peroxide in patients with type 1 and type 2 diabetes were significantly higher than in control patients (Wierusz-Wysocka et al., 1995). There have been the reports (Nishimura \& Kuriyama, 1985) that kidneys and retinal tissues of streptotsitocin-induced rats show increased susceptibility to lipid peroxidation. It has been reported that mitochondrial oxidation metabolism is accelerated in the kidneys of diabetic rats. As a result of our study, the level of LPO increased in rats with diabetes. A high level of LPO during diabetes leads to degenerative and vascular complications. An increase in the level of LPO products may correlate with hyperglycemia due to auto-oxidation of glucose, which causes the formation of free radicals.

It is known (Peruzzu et al., 2015) that there is a positive association between chromium and lipid profile, glycemic control in patients with type 1 diabetes. Researchers (Sundaram et al., 2012) have reported results that indicate chromium as an adjunct to hyperglycemia correction by modifying glucose metabolism in diabetic rats. Similar results of the study (Refaie et al., 2009) also showed the normalization of the activity of antioxidant enzymes in the DM when the chromium compound was added. We found that chromium citrate normalizes GPx activity in both tissues relative to the diabetic group. This improvement was due to the use of $0.1 \mu \mathrm{g} / \mathrm{mL}$ chromium citrate in skeletal muscle tissues, and a similar improvement occurred at $0.2 \mu \mathrm{g} / \mathrm{mL}$ in kidney tissues. Probably, this may indicate a certain organ-tissue difference in the degree of exposure to chromium citrate.

The activity of glutathione reductase in skeletal muscles increased due to the use of chromium citrate in rats. A similar increase was found in the liver tissues by other researchers when chromium compounds were added (Sundaram et al., 2013).

It has been established that GSH is an important molecule in the regulation of oxidative stress, which protects cells from oxidative damage. Supplementing the diet of rats with DM chromium citrate led to an increase in GSH levels in skeletal muscle and kidneys. Also, the administration of chromium pycolinate compounds reduced the incidence of GSH in liver tissues of diabetic rats (Sundaram et al., 2013). Such significant growth of the indicator when using chromium citrate in the amount of $0.1 \mu \mathrm{g} / \mathrm{mL}$ is obviously due to the activation of vitamin C synthesis from L-gulololactone, which prevents the destruction of GSH.

Clinical studies have also shown that the addition of chromium may improve the activity of SOD and catalase in subjects with diabetes (Lai, 2008). Chromium citrate in amounts of $0.1 \mu \mathrm{g} / \mathrm{mL}$ showed a positive effect on activity of SOD in kidney and skeletal muscle tissues. The activity of SOD decreased in skeletal muscle when $0.2 \mu \mathrm{g} / \mathrm{mL}$ chromium citrate was given, but these results are not reliable compared to the diabetic group. Normalization of SOD due to chromium compounds is also described in studies by other authors (Chandirasegaran et al., 2018; Sundaram et al., 2013). Thus, the activation of antioxidant enzymes may be associated with an improvement in insulin sensitivity due to the action of chromium.

We found that the content of TBK-positive substances decreased in skeletal muscle and kidneys of experimental rats which were given chromium compared with diabetic rats. Other studies also found that pycolinate chromium reduced the content of lipid peroxidation products in plasma, kidney tissues and liver of diabetic rats (Chandirasegaran et al., 2018). The concentration in the amount of $0.1 \mu \mathrm{g} / \mathrm{mL}$ of water better 
normalized the indices of lipid peroxidation products in both tissues compared with diabetic II group. The content of TBK-active products had a tendency to increase in group IV of animals which received chromium citrate in the amount $0.2 \mu \mathrm{g} / \mathrm{mL}$ compared with the diabetic group. In this case, chromium citrate in the increased concentration did not show a positive effect. Obviously, chromium inhibits peroxide oxidation of lipids that are exposed to high levels of glucose. It is worth noting that higher doses of chromium citrate do not induce significant dynamic changes compared to the diabetic group. Probably, in this case, the toxic effect of the chromium citrate is apparent, rather than its positive effect on the antioxidant system in animals with DM.

\section{Conclusion}

Consequently, chromium citrate as an additive stimulates the antioxidant system of protection of the body of animals, which prevents secondary diabetic complications, initiated mainly due to peroxide oxidation of lipids and free radicals and leads to significant modulation of lipid and hydrocarbon metabolism. Therefore, chromium citrate can be considered as a prophylactic application for reducing the progression of diabetes mellitus and the risk of complications.

\section{References}

Aragno, M., Mastrocola, R., Catalano, M. G., Brignardello, E., Danni, O., \& Boccuzzi, G. (2004). Oxidative stress impairs skeletal muscle repair in diabetic rats. Diabetes, 53(4), 1082-1088.

Asmat, U., Abad, K., \& Ismail, K. (2016). Diabetes mellitus and oxidative stress A concise review. Saudi Pharmaceutical Journal, 24(5), 547-553.

Bergmeyer, H. U., Gawehn, K., \& Grassl, M. (1974) Methods of enzymatic analysis. In: Bergmeyer, H. U. (Ed.). Verlag Chemie. Wienheim. Vol. 1, 481-482.

Chandirasegaran, G., Elanchezhiyan, C., \& Ghosh, K. (2018). Effects of berberine chloride on the liver of streptozotocin-induced diabetes in albino Wistar rats. Biomedicine and Pharmacotherapy, 99, 227-236.

Christophersen, B. O. (1969). Reduction of linolenic acid hydroperoxide by a glutathione peroxidase. Biochimica et Biophysica Acta, 176(3), 463-470.

Coleman, S. K., Rebalka, I. A., D’Souza, D. M., \& Hawke, T. J. (2015). Skeletal muscle as a therapeutic target for delaying type 1 diabetic complications. World Journal of Diabetes, 6(17), 1323-1336.

Dhama, K., Munjal, A., \& Iqbal, H. M. (2017). Recent advances and novel strategies for the development of biomedical therapeutics: State-of-the-art and future perspectives. International Journal of Pharmacology, 13(7), 929-933.

Dhanya, R., Arya, A. D., Nisha, P., \& Jayamurthy, P. (2017). Quercetin, a lead compound against type 2 diabetes ameliorates glucose uptake via AMPK pathway in skeletal muscle cell line. Frontiers in Pharmacology, 8, 336.

Dubinina, E. E., Yefimova, L. F., Sofronova, L. N., \& Geronimus, A. L. (1988). Aktivnost' i izofermentnyj spektr superoksiddismutazy jeritrocitov i plazmy krovi cheloveka [Activity and isozyme spectrum of superoxide dismutase of erythrocytes and human blood plasma]. Laboratornoe Delo, 10, 30-33 (in Russian).

Evans, J. L., Goldfine, I. D., Maddux, B. A., \& Grodsky, G. M. (2002). Oxidative stress and stress-activated signaling pathways: A unifying hypothesis of type 2 diabetes. Endocrine Reviews, 23(5), 599-622.

Feng, W., Mao, G., Li, Q., Wang, W., Chen, Y., Zhao, T., Li, F., Zou, Y., Wu, H., Yang, L., \& Wu, X. (2015). Effects of chromium malate on glycometabolism, glycometabolism-related enzyme levels and lipid metabolism in type 2 diabetic rats: A dose-response and curative effects study. Journal of diabetes investigation, 6(4), 396-407.

Fu, G. S., Huang, H., Chen, F., Wang, H. P., Qian, L. B., Ke, X. Y., \& Xia, Q. (2007). Carvedilol ameliorates endothelial dysfunction in streptozotocininduced diabetic rats. European Journal of Pharmacology, 567(3), 223-230.

Guan, Y., Cui, Z. J., Sun, B., Han, L. P., Li, C. J., \& Chen, L. M. (2016). Celastrol attenuates oxidative stress in the skeletal muscle of diabetic rats by regulating the AMPK-PGC1 $\alpha$-SIRT3 signaling pathway. International Journal of Molecular Medicine, 37(5), 1229-1238.

Katsumata, K., Katsumata, Y., Ozawa, T., \& Katsumata, T. (1999). Potentiating effects of combined usage of three sulfonylurea drugs on the occurrence of alloxan-induced diabetes in rats. Hormone and Metabolic Research, 25, 125-126.

Korobeynikova, S. N. (1989). Modifikacija opredelenija produktov POL v reakcii s tiobarbiturovoj kislotoj [Modification of definition of lipid peroxidation products in reaction with thiobarbituric acid]. Laboratomoye Delo, 7, $8-9$ (in Russian).

Korolyuk, M. A., Ivanova, M. I., Maiorova I. T., \& Tokarev, V. E. (1988). Metod opredelenija aktivnosti katalazy [Method for determination of catalase activity]. Laboratornoye Delo, 1, 16-19 (in Russian).

Krause, M. P., Al-Sajee, D., D'Souza, D. M., Realka, I. A., Moradi, J., Riddell, M. C., \& Hawke, T. J. (2013). Impaired macrophage and satellite cell infiltra- tion occurs in a muscle-specific fashion following injury in diabetic skeletal muscle. PLoS One, 8(8), e70971.

Król, E., \& Krejpcio, Z. (2010). Chromium (III) propionate complex supplementation improves carbohydrate metabolism in insulin-resistance rat model. Food and Chemical Toxicology, 48(10), 2791-2796.

Kumawat, M., Sharma, T. K., Singh, I., Singh, N., Ghalaut, V. S., Vardey, S. K., \& Shankar, V. (2013). Antioxidant enzymes and lipid peroxidation in type 2 diabetes mellitus patients with and without nephropathy. North American Journal of Medical Sciences, 5(3), 213-219.

Lai, M. H. (2008). Antioxidant effects and insulin resistance improvement of chromium combined with vitamin $\mathrm{C}$ and $\mathrm{E}$ supplementation for type 2 diabetes mellitus. Journal of Clinical Biochemistry and Nutrition, 43(3), 191198.

Lewicki, S., Zdanowski, R., Krzyzowska, M., Lewicka, A., Debski, B., Niemcewicz, M., \& Goniewicz, M. (2014). The role of chromium III in the organism and its possible use in diabetes and obesity treatment. Annals of Agricultural and Environmental Medicine, 21(2), 331-335.

Li, H., Meng. X., Wan, W., Liu, H., Sun, M., Wang, H., \& Wang, J. (2018). Effects of chromium picolinate supplementation on growth, body composition, and biochemical parameters in Nile tilapia Oreochromis niloticus. Fish Physiology and Biochemistry, 44(5), 1265-1274.

Lipko, M., \& Debski, B. (2018). Mechanism of insulin-like effect of chromium (III) ions on glucose uptake in $\mathrm{C} 2 \mathrm{C} 12$ mouse myotubes involves ROS formation. Journal of Trace Elements in Medicine and Biology, 45, 171-175.

Lowry, O. H., Rosenbrough, N. J., Farr, A. L., \& Randall, R. (1951). Protein measurement with the Folin phenol reagent. Journal of Biological Chemistry, 193(1), 265-275.

Martin, J., Wang, Z. Q., Zhang, X. H., Wachtel, D., Volaufova, J., Matthews, D. E., \& Cefalu, W. T. (2006). Chromium picolinate supplementation attenuates body weight gain and increases insulin sensitivity in subjects with type 2 diabetes. Diabetes Care, 29(8), 1826-1832.

Mironchik, V. V. (1998). Sposob opredeleniya gidroperekisey lipidov v biologicheskikh tkanyakh [Method of determining the content of lipid hydroperic acids in biological tissues]. Avtorskoye Svidetel'stvo № 1084681 SSSR, MKI G №33/48. (SSSR). № 3468369/2813; Byul. № 13.

Moin, V. M. (1986). Prostoj i specificheskij metod opredelenija aktivnosti glutationperoksidazy v jeritrocitah [A simple and specific method for the determination of glutathione peroxidase in erythrocytes]. Laboratornoye Delo, 12, 724-727 (in Russian).

Nagarjun, S., Dhadde, S. B., Veerapur, V. P., Thippeswamy, B. S., \& Chandakavathe, B. N. (2017). Ameliorative effect of chromium-D-phenylalanine complex on indomethacin-induced inflammatory bowel disease in rats. Biomedicine and Pharmacotherapy, 89, 1061-1066.

Neve, J., Wasociz, W., Quivy, D., Parij, N., Van Gossum, A., \& Peretz, A. (1995). Lipid peroxidation assessed by serum thiobarbituric acid reactive substances in healthy subjects and in patients with pathologies known to affect trace element status. Biological Trace Element Research, 41, 147-153.

Nishimura, C., \& Kuriyama K. (1985). Alteration of lipid peroxide and endogenous antioxidant contents in retina of streptozotocin-induced diabetic rats: Effect of vitamin A administration. The Japanese Journal of Pharmacology, 37(4), 365-372.

Ozaki, K., Terayama, Y., Matsuura, T., \& Narama, I. (2018). Effect of combined dyslipidemia and hyperglycemia on diabetic peripheral neuropathy in alloxan-induced diabetic WBN/Kob rats. Journal of Toxicologic Pathology, 31(2), 125-133.

Pecoits-Filho, R., Abensur, H., Betônico, C. C., Machado, A. D., Parente, E. B., Queiroz, M., Salles, J. E., Titan, S., \& Vencio, S. (2016). Interactions between kidney disease and diabetes: dangerous liaisons. Diabetology and Metabolic Syndrome, 8, 50 .

Peruzzu, A., Solinas, G., Asara, Y., Forte, G., Bocca, B., Tolu, F., Malaguarnera, L., Montella, A., \& Madeddu, R. (2015). Association of trace elements with lipid profiles and glycaemic control in patients with type 1 diabetes mellitus in Northern Sardinia, Italy: An observational study. Chemosphere, 132, 101-107.

Praveena, S., Pasula, S., \& Sameera, K. (2013). Trace elements in diabetes mellitus. Journal of Clinical and Diagnostic Research, 7(9), 1863-1865.

Qiao, W., Peng, Z. L., Wang, Z. S., Wei, J., \& Zhou, A. G. (2009). Chromium improves glucose uptake and metabolism through upregulating the mRNA levels of IR, GLUT4, GS, and UCP3 in skeletal muscle cells. Biological Trace Element Research, 131(2), 133-142.

Refaie, F. M., Esmat, A. Y., Mohamed, A. F., \& Aboul Nour, W. H. (2009). Effect of chromium supplementation on the diabetes induced-oxidative stress in liver and brain of adult rats. Biometals, 22(6), 1075-1087.

Siddiqui, K., Bawazeer, N., \& Joy, S. S. (2014). Variation in macro and trace elements in progression of type 2 diabetes. Scientific World Journal, 2014, 461591.

Stallings, D. M., Hepburn, D. D., Hannah, M., Vincent, J. B., \& O’Donnell, J. (2006). Nutritional supplement chromium picolinate generates chromosomal 
aberrations and impedes progeny development in Drosophila melanogaster. Mutation Research, 610, 101-113.

Stanieka, H., \& Wójciak, R. W. (2018). The combined effect of supplementary $\mathrm{Cr}$ (III) propionate complex and iron deficiency on the chromium and iron status in female rats. Journal of Trace Elements in Medicine and Biology, 45, $142-149$.

Sundaram, B., Aggarwal, A., \& Sandhir, R. (2013). Chromium picolinate attenuates hyperglycemia-induced oxidative stress in streptozotocin-induced diabetic rats. Journal of Trace Elements in Medicine and Biology, 27(2), 117121.

Sundaram, B., Singhal, K., \& Sandhir, R. (2012). Ameliorating effect of chromium administration on hepatic glucose metabolism in streptozotocin-induced experimental diabetes. Biofactors, 38(1), 59-68.

Valera, P., Zavattari, P., Albanese, S., Cicchella, D., Dinelli, E., Lima, A., \& De Vivo, B. (2014). A correlation study between multiple sclerosis and type 1 diabetes incidences and geochemical data in Europe. Environmental Geochemistry and Health, 36(1), 79-98.

Vincent, J. B. (2015). Is the pharmacological mode of action of chromium (III) as a second messenger? Biological Trace Element Research, 166(1), 7-12.

Vlizlo, V. V., Fedoruk, R. S., \& Ratych, I. B. (2012). Laboratorni metody doslidzhen u biolohiyi, tvarynnytstvi ta veterynarniy medytsyni [Laboratory methods of research in biology, veterinary medicine: A guide]. Spolom, Lviv (in Ukrainian).

Wang, S., Wang, J., Zhang, X. N., Hu, L., Fang, Z., Huang, Z., \& Shi, P. (2016). Trivalent chromium alleviates oleic acid induced steatosis in SMMC-7721 cells by decreasing fatty acid uptake and triglyceride synthesis. Biometals, 29(5), 881-892.

Wierusz-Wysocka, B., Wysocki, H., Byks, H., Zozulinska, D., Wykretowicz, A., \& Kazmierczak, M. (1995). Metabolic control quality and free radical activity in diabetic patients. Diabetes Research and Clinical Practice, 27(3), 193-197.

Xie, M. J., Yang, X. D., Liu, W. P., Yan, S. P., \& Meng, Z. H. (2010). Insulin-enhancing activity of a dinuclear vanadium complex: 5-chloro-salicylaldhyde ethylenediamine oxovanadium (V) and its permeability and cytotoxicity. Journal of Inorganic Biochemistry, 104, 851-857.

Yang, J. J., Xu, Y. Y., Qian, K., Zhang, W., Wu, D., \& Wang, C. (2016). Effects of chromium-enriched Bacillus subtilis KT260179 supplementation on growth performance, caecal microbiology, tissue chromium level, insulin receptor expression and plasma biochemical profile of mice under heat stress. British Journal of Nutrition, 115(5), 774-781.

Yang, X., Palanichamy, K., Ontko, A. C., Rao, M. N., Fang, C. X., Ren, J., \& Screejayan, N. (2005). A newly synthetic chromium complex-chromium (phenylalanine) $)_{3}$ improves insulin responsiveness and reduces whole body glucose tolerance. FEBS Letters, 579(6), 1458-1464.

Yin, R. V., \& Phung, O. J. (2015). Effect of chromium supplementation on glycated hemoglobin and fasting plasma glucose in patients with diabetes mellitus. Nutrition Journal, 14, 14.

Zhang, Q., Xiao, X., Zheng, J., Li, M., Yu, M., Ping, F., Wang, X., \& Wang, T. (2017). Maternal chromium restriction modulates miRNA profiles related to lipid metabolism disorder in mice offspring. Experimental Biology and Medicine (Maywood), 242(14), 1444-1452. 